\title{
Portfolio Investment diversification at Global stock market: A Cointegration Analysis of Emerging BRICS(P) Group
}

\author{
Sarfaraz A. BHUTTO ${ }^{1}$, Rizwan Raheem AHMED ${ }^{2}$, Dalia STREIMIKIENE ${ }^{3 *}$, \\ Saifullah SHAIKH ${ }^{4}$ and Justas STREIMIKIS ${ }^{5,6}$
}

Authors' affiliations and addresses:

${ }^{1}$ Institute of Commerce, Shah Abdul Latif

University, Khairpur, Sindh, Pakistan

e-mail: sarfaraz_ahmed0333@yahoo.com

${ }^{2}$ Faculty of Management Sciences, Indus University, Block-17, Gulshan, Karachi-75300, Pakistan

e-mail: rizwanraheemahmed@gmail.com

${ }^{3}$ Institute of Sport Science and Innovations, Lithuanian Sports University, Sporto str. 6, LT4422, Lithuania

e-mail: dalia.streimikiene@1su.lt

${ }^{4}$ Institute of Commerce, Shah Abdul Latif University, Khairpur, Sindh, Pakistan e-mail: $\underline{\text { saifullah.shaikh@salu.edu.pk }}$

${ }^{5}$ Lithuanian Institute of Agrarian Economics, Vivulskio g. 4A-13, Vilnius, Lithuania.

${ }^{6}$ The University of Economics and Human

Science in Warsaw, Okopowa 59, 01-043

Warsaw, Poland

e-mail: jutas.streimikis@gmail.com

*Correspondence:

Dalia Streimikiene, Institute of Sport Science and Innovations, Lithuanian Sports University, Sporto str. 6, LT-4422, Lithuania e-mail: dalia.streimikiene@1su.lt

How to cite this article:

Bhutto, S. A., Ahmed, R. R., Streimikiene, S. Shaikh, S. and Streimikis, S. (2020). Portfolio Investment diversification at Global stock market: A Cointegration Analysis of Emerging BRICS(P) Group. Acta Montanistica Slovaca, Volume 25 (1), 57-69

DOI:

https://doi.org/10.46544/AMS.v25i1.6

\begin{abstract}
This study investigates the outcomes of emerging BRICS(P) groups at the global stock market. The Emergence of this Group helps the investors in the diversification of international portfolio funds. However, economic and financial globalization assimilated the world's leading economies to provide an interdependent investment portfolio structure for investors and savings in the transformation and allocation of funds. The diversification of the international stock market may bounce the investors of BRICS(P) Group to maximize the expected returns along with a certain level of risk placement. This study prefers to use Auto-Regressive Distributed Lag (A.R.D.L.) method to evaluate the outcomes of investment diversification and to investigate the short-term and long-term changing patterns of the sampled stock exchange markets in the BRICS(P) nations. The findings of this study show that a significant investment portfolio diversification may originate benefits if the funds become merged among the B.R.I.C.S. (Brazil, Russia, India, China, and South Africa) nations. Moreover, this study made a separate point of view for the investment funds of India and Pakistan. The study investigates that the funds of these two nations are assimilated, and the appropriate diversification of investment may exist through the assimilation of these two economies. The results would suggest the international and native investors merge their investment proposals among these economies and to construct a well-diversified portfolio because a shared value of risk protects the investors. It gives opportunities to earn desirable returns. The study has implications on all sectors of the economy, including mining as well as natural resource prices.
\end{abstract}

\section{Keywords}

Portfolio diversification, emerging BRICS(P) group, financial globalization, global stock markets, A.R.D.L. method

(C) 2020 by the authors. Submitted for possible open access publication under the terms and conditions of the Creative Commons Attribution (CC BY) license (http://creativecommons.org/licenses/by/4.0/). 


\section{Introduction}

In the context of portfolio investment, the modern theories of portfolio support the investors (native/international) to minimize the portfolio risk and maximize the investment return. The global framework of portfolio investment gives more provision for investors in several dimensions of risk and return (OpokuMensah et al., 2019; Lekovic, 2018; Bahlous \& Yusof, 2014). Most of the countries are not consistent with economic prosperity. They face quick upswings and downturns in the economic cycle, though; international investment diversification reduces the volatility of investor's returns. The preliminary research studies on the global investment found a nonlinear relationship between foreign financial and instinctive/domestic financial securities due to the non-diversification of investment funds. Grubel (1968), Levy and Sarnat (1970), and Salisu and Oloko (2015) are the pioneer researchers for these empirical studies. Contrary, it is found that this nonlinear relationship may convert to linearity if we assess international investment diversification (Mei \& McNown, 2019; Cosset \& Suret, 1995).

Moreover, they suggested that the structure of emerging financial markets would become beneficial for investors as well as for economies. If we say that all the stock markets (National/International) are Volatile, that would not be wrong. However, the portfolio investment theories propose, "Stock markets are volatile, a good speculator may forecast well by observing the ongoing trends of the financial market." A country contains several economic and non-economic risks that push the investor to diversify the investment to other countries, like low G.D.P., devaluation of the currency, increasing interest rate, political and market risks (Okwu et al., 2020; Bahlous \& Yusof, 2014; Grubel, 1968). Therefore, the globalization of financial markets gives opportunities to hold a well-diversified international portfolio. The prospect of foreign portfolio investment cantered the speculators on investing in global financial assets, which leads them to earn suitable returns and a minimal level of risk (Ozturk \& Karabulut, 2020; Li, Sarkar, \& Wang, 2003). However, the trade policies of several economies have become substantial to crop a liberal financial integration at the international financial market. This is the reason for the growth in financial-economic and technological globalization. Investors are risk-averse due to this behaviour. They derive benefits from the international investment diversification to speculate best in risk and return portfolio. In a study, it was investigated that with time, the investors may derive fewer benefits from investment diversification due to the increasing interdependence of financial markets (Huang \& Fang, 2019; Longin \& Solnik, 1995).

Moreover, some previous studies support that the volatile nature of stock markets may increase risk factors in the scenario of the financial crisis (Wang, 2019; Batareddy, Gopalaswamy, \& Huang, 2012; Guidi \& Ugur, 2014; Levy \& Sarnat, 1970). The interdependence of financial markets set a barrier for an active investor to diversify fund. On the other hand, in the long run, it is difficult for an inactive investor to reap a maximum return in a different financial environment. In the last decade, the developed economies assimilated with the developing economies. This Emergence from the developed world to the developing world tends speculators to invest in the new emerging financial market (Ahmad et al., 2016).

Moreover, the integration of developed economies inclines the confidence of investors to maximize return with a certain level of risk. In this regard, BRICS (Brazil, Russia, India, China, and South Africa) Group has made a significant contribution among the emerging economies (Huang \& Fang, 2019). It is a leading emerging Group in the international economic forum, which is potentially high for investment. The statistics of the World Economic Forum (W.E.F.) shows that China has beaten the economy of Japan (Country of Qualitative Products). Nowadays, China has become the world's $2^{\text {nd }}$ largest economy, contributing a significant role in the world economy (Rao \& Padhi, 2020).

Moreover, the economies of Brazil, Russia, and India have taken a specific potion in the G7 Group, particularly; Italy is affected by the G7 economies. In our observation, the BRICS Group is a rising start for investors because of two reasons. First, the BRICS Group has become a centralized unit to captivate the aggregate investment in the international market (Rao \& Padhi, 2020). Secondly, these countries are also categorized as the largest consumers of goods due to the high population. Though, the growing demand for products and services exist, like India and China. The BRICS group tends to develop Social Overhead Capital (S.O.C.) to captivate the international flow of funds. The development in Social overhead capital includes the infrastructure of the country like Better Transportation ways (Freight, Carriage), Suitable Security Plans, and fast communication (Sivarethinamohan \& Sujatha, 2019). A smooth Social Overhead capital attracts the international and domestic investors, and it works as a supplement in the trade and development cycle of an economy. Some other factors also bring these emerging economies as a central hub for investment like it captures more than onefourth area of the Globe (Huang et al., 2019; Ahmad et al., 2016).

Moreover, a high level of the population, which covers $40 \%$ of the world's population, influences these areas. It contributes fifteen percent in the world's Gross Domestic Product (G.D.P.) rate. It is predicted by Goldman Sachs, that the BRIC (Brazil, Russia, India, China except for South Africa) economies are expected to achieve the target of $\$ 128$ trillion in their nominal G.D.P. rate by 2050 . However, the G7 economies would reach only 66 trillion dollars at that time. BRIC economies may take up $41 \%$ of the world's stock exchange market by 
2030 (Huang et al., 2019). Furthermore, China is one of the leading nations among BRICS Group, though it is expected that soon the Chinese stock market would become the world's largest stock hub, and the U.S.A. capital market may have been crushed (Rao \& Padhi, 2020; Zonouzi et al., 2014). A massive change is seen in several economies after the price hit in the oil market; some economies have drawn benefits and others sacrificed. I.M.F. (International Monetary Fund) and W.E.F. (World Economic Forum) suggests, "The recent change in the oil price put a good scratch at the economy of Pakistan." It is observed that Pakistan is accompanying some major economic transformation Like C.P.E.C. (China Pakistan Economic Corridor), though China's associated commercial projects bring Pakistan at financial Brink (Ghauri et al., 2020; Ahmed et al., 2018b). The economy has emerged to an international market with an index of M.S.C.I. (Morgan Stanley Capital Market). The Pakistan Stock Exchange (P.S.E.) performing well at the KSE-100 index, and according to Bloomberg KSE-100, the M.S.C.I. ranked as a $5^{\text {th }}$ best stock exchange in the world. Moreover, this Emergence of Stock Markets is considered best in Asian Equity Market (Fatima \& Shamim, 2020).

The above-stated facts stipulate to investigate the advantages of portfolio investment in these emerging economies and benefits associated with a well-diversified portfolio. However, it is articulated in the previous studies that portfolio diversification gives opportunities to maximize the return on investment with a certain level of risk, though; investment diversification sinks the benefits of the exchange rate, upswings at the international equity market. Diversification based on SWOT analyses of several firms, and variation in the economic policies, etc. (Ghauri et al., 2020; Guidi \& Ugur, 2014; Mobarek \& Li, 2014; Salisu \& Oloko, 2015; Sukumaran, Gupta, \& Jithendranathan, 2015). Therefore, this study tends to find the outcomes of portfolio investment diversification among the BRICS(P) Group. Moreover, this study raises the following questions to answer.

- What benefits of investment diversification can be drawn by an investor with the Emergence of stock Markets in BRICS(P) Group?

- What could be the short-run and long-run relationship among the stock markets of BRICS(P) Group?

The answers to the above-stated questions tend to enlighten and educate international investors to draw maximum benefits by investing in a portfolio. It also gives remedies to minimize portfolio-associated risk. Investors may feel satisfaction from such provisions of portfolio diversification, which would give them maximum returns, though, these analyses would help the investors to figure out an optimal and well-diversified investment portfolio among the BRICS(P) Group. This study is based on secondary data; Therefore, Time series patterns have used to comprehend short and long-term investment forces among BRICS(P) Group. Furthermore, the linear relationship among BRICS(P) Group is observed by the A.R.D.L. approach and correlation.

This study has outlined five parts; the $1^{\text {st }}$ part was related to the introduction of the study topic. Moreover, $2^{\text {nd }}$ part would explain a detailed review of the literature, and some evidence from past studies on the international portfolio diversification and $3^{\text {rd }}$ part centres the data set and methodology, which we used to know the outcomes of the study. The study results would be explained in the $4^{\text {th }}$ part. Finally, the last and $5^{\text {th }}$ part of this study would summarize the study findings as to the conclusion and future research suggestions, and implications would also be included.

\section{Substantiation from previous literature}

The concept of Portfolio Investment was primarily introduced by (Markowitz, 1952) and some supporting keystones of C.A.P. (Capital Assets Pricing) Model was founded by (Lintner, 1975; Sharpe, 1964). The Markowitz Portfolio theory explains the real theme of a financial asset. It suggests the way to select financial security, which holds some unique characteristics. Moreover, at the same time, it gives analyses of implicit/explicit factors of a portfolio, which can uplift the aggregate value of investment profitable with a minimal level of risk. Furthermore, the CAPM approach includes three key elements that help estimate the expected return on financial security; these three elements such as 1) the risk-free rate of return, 2) Market risk Premium and 3) Beta values (Ozturk \& Karabulut, 2020).

The first two elements assess non-diversifiable risk and beta measure the risk relevancy of individual financial security. The covariance of financial securities measures the composition of a well-diversified portfolio. In simple words, it measures the real phenomena of the ongoing market to predict the expected return with a specific portion of the risk. In a nutshell, Portfolio theory refers to the improving behaviour of investors in a portfolio context (Wang, 2019). At the same time, the CAMP approach depicts an equilibrium point of aggregate economic practice in which every investor tends to invest with a relevant percentage of risk. The above theories conclude that all investors behave rationally to make an appropriate portfolio structure, and the risk-averse nature pushes investors to build a well-diversified investment portfolio (Parveen et al., 2020). In this regard, the international portfolio gives investors more provision to circulate their investment in several economies by enjoying maximum returns with minimum risk. Therefore, the foreign portfolio investment is more dominated than the domestic one (Tsagkanos et al., 2019; Boubaker \& Jouini, 2014). 
Many empirical studies have focused on the benefits derived from international diversification of funds at emerging financial markets. One of the significant studies on international diversification of investment was investigated in recent years (Ahmed et al., 2018; Mobarek \& Li, 2014). They found that cointegration among BRICS economies is irregular or asymmetry, and it is affected by the financial crises which have taken place in the financial market of the U.S.A. Though, newer financial and economic policies of the U.S.A. have become failed to hit financial damage at BRICS Group (Okwu et al., 2020). A regression technique was used to find the results. Previously, some supporting studies were conducted by Laurenceson and Chai (2003), and Patev et al. (2006), they had the view that no long-run relationship is expected between two broad financial markets, the American financial market and Central Eastern Europe Financial market (C.E.E.F.M.). They pointed out the declining rate of investment diversification due to the financial crisis. However, they state that investors may drive minimal provision from diversification in the period of the financial crisis and may gain short-run benefits after the financial crisis. Another study gives the opposite view of the C.E.E.F.M. role in the international part (Sivarethinamohan \& Sujatha, 2019). It suggests that there is a high tendency of C.E.E.F.M. to the developed Southeastern EU markets. They are highly correlated and interdependent in the diversification of funds, especially during economic shock. The maximum benefits may drive investors at prevailing market returns and certain risk percentages (Tsagkanos et al., 2019; Guidi \& Ugur, 2014).

The economic shock in the Japanese Stock Market and the American stock market affect Asian countries' financial markets (Batareddy et al., 2012). Moreover, it is investigated that the World Equity market has integrated with emerging and developed financial markets (Johnson \& Soenen, 2009). The past studies have significantly stated the advantages of international investment diversification. It is stated that the financial market (Stock Market) of the U.S.A. is dominated over the Asian Financial Markets (Stock Market), these are interdependent or cointegrated (Mei \& McNown, 2019; Dhanaraj, Gopalaswamy, \& Babu, 2013). Moreover, they stated that the economy of the U.S.A. is declared as the world's largest economy. Though, being a large economy, they are rich in industries and major supplier of advanced technological products to Asian countries, the benefits are mutually exclusive for both US and Asian economies. Therefore, many investors are willing to invest in these cointegrated financial markets to enjoy the mutual benefits of investment diversification. However, the Economic shock or financial crisis that may take place into Asian Economies may affect the US financial market (Dhanaraj et al., 2013). A comparative study between EMU and MU is conducted by Dunis et al. (2013). They were of the view that new EMU members build a certain degree of economic acceleration over the EU Contrary, the same degree of economic acceleration in not observed in EMU. In the context of international investment diversification, the Islamic way of financing tends to be the maximum provision to invest in the selected Islamic-ruled economies (Bhoi, 2019; Bahlous \& Yusof, 2014).

A comparative study was conducted to observe the co-moment of stock markets in the U.S.A., UK, Germany, and Japan. The study found the outcomes of the Japanese stock market, making a relatively lower degree of co-moment with the stock markets of the U.S.A., UK, and Germany. In contrast, a high degree is observed in the German stock market with the U.S. and UK (Rua \& Nunes, 2009). According to Mobarek and Li (2014), the Association of Southeast Asian Nations (ASEAN) would not pin the benefits for international investors (No-native). However, Portfolio Diversification would not be benefited to them. Contrary, the benefits may drive from emerging economies (Ahmad et al., 2016). The maximum provision of return and minimization of risk are the key benefits of international diversification of Portfolio Investment, particularly in emerging financial markets (Ahmed et al., 2018a; Zonouzi et al., 2014). The World Equity market has reduced a little portion of portfolio diversification benefits, and it is due to the interdependence of financial markets. Moreover, the benefits of Portfolio diversification may increases if investors of emerging economies put a short sell barrier to move forward for the US stock market ( $\mathrm{Li}$ et al., 2003). One of the significant studies is carried out on the emerging economies of South Asian Markets, and it considered three leading countries like India, Srilanka, and Pakistan.

The results of this show a significant relationship among all three countries, and they may drive portfolio diversification (Sukumaran et al., 2015). The geographical location and economic conditions may push investors to reap maximum benefits from Portfolio diversification with minimal risk (Fatima \& Shamim, 2020; Valadkhani, Salisu \& Oloko, 2015; Chancharat, \& Harvie, 2008). According to Hoque (2007), a week correlation is observed between Bangladeshi and the Japanese Stock Market. However, the stock markets of the U.S.A. and Bangladesh are highly correlated. They were of the view that due to the similarity between stock markets, not much benefit could be derived from portfolio diversification. Emerging economies refer to frontier economies, an intermediate economic channel for an investor to diversify their funds from developed economies to developing economies. It can be done in both the short- and long run. The quick upswing and consistency prompt the expectations of investors to forecast maximum return with a small percentage of risk (Opoku-Mensah et al., 2019; Tsagkanos et al., 2019; Sukumaran et al., 2015). 


\section{Material and Methods}

Data sources. This study aims to investigate the short and long-run investment relationship between the BRICS-(P) Group. To achieve the oriented object of this study, we collected secondary data from Yahoo Finance, which is an authentic source to collect refined financial data of several stock indices. This study includes seven indices only. Linking the BRICS-(P) Group, we cover the sampled countries of Brazil, Russia, India, China, South Africa, and Pakistan, which is suitable to represent the concept of emerging economies at a global level. This study induced to collect Monthly data from November-2012 to October-2018. We eliminated the data of the Dividends of firms, this was carried out by Lekovic (2018), and Bahlous and Yusof (2014) studied. The primary purpose of this study is to explore the benefits of international portfolio diversification. Though, there is no need to enter the data of dividends because it influences the intrinsic policies of an individual firm.

Estimation techniques. This study induces to analyze the short-term and long-term relationship among BRICS-(P) group by using the Auto-Regressive Distributed Lag (A.R.D.L.) approach (Fatima \& Shamim, 2020; Pesaran, Shin, \& Smith, 1996). It is considered as a regression model that includes appropriate numbers of lags for each independent variable (Ghauri et al., 2020; Laurenceson \& Chai, 2003). Furthermore, the A.R.D.L. model includes I (1) and I (0) (But not I (2)) to ensure the past and past and present values of chosen variables. The A.R.D.L. approach supports the non-stationary data set. Moreover, it estimates the appropriate cointegration for short-term and long-term coefficient, and it is not necessary to have a unique integration level among study variables. Still, it would be fine in their efficiency and unbiasedness (Narayan P.K. \& Narayan S., 2006). We have used the following six A.R.D.L. models shown by Eq. (1) to Eq. (6) as follows:

Model 1.

$$
\begin{aligned}
& \text { Pakista }_{t}=\alpha_{0}+\alpha_{1} \text { Brazil }+\alpha_{2} \text { Russia }_{t}+\alpha_{3} \text { India }_{t}+\alpha_{4} \text { China }_{t}+\alpha_{5} \text { SouthAfrica }_{t} \\
& +\alpha_{6} U S A(S \& \text { P } 500)_{t}+\varepsilon_{t}
\end{aligned}
$$

Model 2.

$$
\begin{aligned}
& \text { Brazil }_{t}=\alpha_{0}+\alpha_{1} \text { Pakista }_{t}+\alpha_{2} \text { Russia }_{t}+\alpha_{3} \text { India }_{t}+\alpha_{4} \text { China }_{t}+\alpha_{5} \text { SouthAfrica }_{t} \\
& +\alpha_{6} U S A(S \& \text { P500 })_{t}+\varepsilon_{t}
\end{aligned}
$$

Model 3.

$$
\begin{aligned}
& \text { Russia }_{t}=\alpha_{0}+\alpha_{1} \text { Brazil }+\alpha_{2} \text { Pakista }_{t}+\alpha_{3} \text { India }_{t}+\alpha_{4} \text { China }_{t}+\alpha_{5} \text { SouthAfrica }_{t} \\
& \left.+\alpha_{6} \operatorname{USA}_{(S \& \text { P }} \text { P00 }\right)_{t}+\varepsilon_{t}
\end{aligned}
$$

\section{Model 4.}

$$
\begin{aligned}
& \text { India }_{t}=\alpha_{0}+\alpha_{1} \text { Brazil }+\alpha_{2} \text { Russia }_{t}+\alpha_{3} \text { Pakista }_{t}+\alpha_{4} \text { China }_{t}+\alpha_{5} \text { SouthAfrica }_{t} \\
& +\alpha_{6} U_{S A}(S \& \text { P500 })_{t}+\varepsilon_{t}
\end{aligned}
$$

Model 5.

China $_{t}=\alpha_{0}+\alpha_{1}$ Brazil $+\alpha_{2}$ Russia $_{t}+\alpha_{3}$ India $_{t}+\alpha_{4}$ Pakista $_{t}+\alpha_{5}$ SouthAfrica $_{t}$

Model 6.

$+\alpha_{6} U S A(S \& P 500)_{t}+\varepsilon_{t}$

SouthAfrica $_{t}=\alpha_{0}+\alpha_{1}$ Brazil $+\alpha_{2}$ Russia $_{t}+\alpha_{3}$ India $_{t}+\alpha_{4}$ China $_{t}+\alpha_{5}$ Pakista $_{t}$

$+\alpha_{6} U S A(S \& P 500)_{t}+\varepsilon_{t}$

The study chooses seven indices. Table 1 exhibited the list of the selected indices of BRICS-(P) Group.

Tab. 1. BRIC- (P) Group indices

\begin{tabular}{c|c}
\hline Country & Index \\
\hline Brazil & IBOVESPA \\
\hline Russia & M.I.C.E.X. \\
\hline India & BSE SENSEX \\
\hline China & S.S.E. \\
\hline South Africa & E.Z.A. \\
\hline Pakistan & KSE-100 \\
\hline USA & S\&P500 \\
\hline
\end{tabular}


The first six indices concern with the emerging BRICS(P) Group, and the last index measures the combined financial performance of emerging economies at the global level. Furthermore, we have used the Error correction model to assess the short-term relationship of investment portfolio diversification. The E.C.M. may extract from the A.R.D.L. model by simple linearity if the model specification is unbiased (Fatima \& Shamim, 2020; Cosset \& Suret, 1995). Moreover, without having a change in long-term information, we can drive short-term results by using E.C.M. (Batareddy et al., 2012). The following models from Eq. (7) to Eq. (12) specify the E.C.M.s for selected variables of the study.

\section{Model 7.}

$$
\begin{aligned}
& \Delta \ln \text { Pakista }_{t}=\alpha_{0}+\sum_{j=1}^{k 1} b_{j} \Delta \ln \text { Brazil }_{t-j}+\sum_{j=0}^{k 2} c_{j} \Delta \ln \text { Russia }_{t-j}+\sum_{j=0}^{k 3} d_{j} \Delta \ln \operatorname{India}_{t-j} \\
& +\sum_{j=0}^{k 4} e_{j} \Delta \ln \text { China }_{t-j}+\sum_{j=0}^{k 5} f_{j} \Delta \ln \text { SouthAfrica }_{t-j}+\sum_{j=0}^{k 6} g_{j} \Delta \ln U S A(S \& \text { P500 })_{t-j} \\
& +n_{1} \ln \text { Pakista }_{t-1}+n_{2} \ln \text { Brazil }_{t-1}+n_{3} \ln \text { Russia }_{t-1}+n_{4} \ln \text { India }_{t-1} \\
& +n_{5} \ln \text { China }_{t-1}+n_{6} \ln \text { SouthAfrica }{ }_{t-1}+n_{7} \ln U S A(S \& \text { P500); }
\end{aligned}
$$

\section{Model 8.}

$$
\begin{aligned}
& \Delta \ln \text { Brazil }_{t}=\alpha_{0}+\sum_{j=1}^{k 1} b_{j} \Delta \ln \text { Pakista }_{t-j}+\sum_{j=0}^{k 2} c_{j} \Delta \ln \text { Russia }_{t-j}+\sum_{j=0}^{k 3} d_{j} \Delta \ln \text { India }_{t-j} \\
& +\sum_{j=0}^{k 4} e_{j} \Delta \ln \text { China }_{t-j}+\sum_{j=0}^{k 5} f_{j} \Delta \ln \text { SouthAfrica }_{t-j}+\sum_{j=0}^{k 6} g_{j} \Delta \ln U S A(S \& \text { \&500 })_{t-j} \\
& +n_{1} \ln \text { Pakistan }_{t-1}+n_{2} \ln \text { Brazil }_{t-1}+n_{3} \ln \text { Russia }_{t-1}+n_{4} \ln \text { India }_{t-1} \\
& +n_{5} \ln \text { China }_{t-1}+n_{6} \ln \text { SouthAfrica } \\
& t-1
\end{aligned}
$$

\section{Model 9.}

$$
\begin{aligned}
& \Delta \ln \text { Russia }_{t}=\alpha_{0}+\sum_{j=1}^{k 1} b_{j} \Delta \ln \text { Brazil }_{t-j}+\sum_{j=0}^{k 2} c_{j} \Delta \ln \text { Pakistan }_{t-j}+\sum_{j=0}^{k 3} d_{j} \Delta \ln \text { India }_{t-j} \\
& +\sum_{j=0}^{k 4} e_{j} \Delta \ln \text { China }_{t-j}+\sum_{j=0}^{k 5} f_{j} \Delta \ln \text { SouthAfrica }_{t-j}+\sum_{j=0}^{k 6} g_{j} \Delta \ln U S A(S \& P 500)_{t-j} \\
& +n_{1} \ln \text { Pakistan }_{t-1}+n_{2} \ln \text { Brazil }_{t-1}+n_{3} \ln \text { Russia }_{t-1}+n_{4} \ln \text { India }_{t-1} \\
& +n_{5} \ln \text { China }_{t-1}+n_{6} \ln \text { SouthAfrica } \\
& t-1
\end{aligned}
$$

\section{Model 10.}

$$
\begin{aligned}
& \Delta \ln \text { India }_{t}=\alpha_{0}+\sum_{j=1}^{k 1} b_{j} \Delta \ln \text { Brazil }_{t-j}+\sum_{j=0}^{k 2} c_{j} \Delta \ln \text { Russia }_{t-j}+\sum_{j=0}^{k 3} d_{j} \Delta \ln \text { Pakista }_{t-j} \\
& +\sum_{j=0}^{k 4} e_{j} \Delta \ln \text { China }_{t-j}+\sum_{j=0}^{k 5} f_{j} \Delta \ln \text { SouthAfrica }_{t-j}+\sum_{j=0}^{k 6} g_{j} \Delta \ln U S A(S \& \text { P500 })_{t-j} \\
& +n_{1} \ln \text { Pakistan }_{t-1}+n_{2} \ln \text { Brazil }_{t-1}+n_{3} \ln \text { Russia }_{t-1}+n_{4} \ln \text { India }_{t-1} \\
& +n_{5} \ln \text { China }_{t-1}+n_{6} \ln \text { SouthAfrica } \\
& t-1
\end{aligned}
$$




\section{Model 11.}

$$
\begin{aligned}
& \Delta \ln \text { China }_{t}=\alpha_{0}+\sum_{j=1}^{k 1} b_{j} \Delta \ln \text { Brazil }_{t-j}+\sum_{j=0}^{k 2} c_{j} \Delta \ln \text { Russia }_{t-j}+\sum_{j=0}^{k 3} d_{j} \Delta \ln \text { India }_{t-j} \\
& +\sum_{j=0}^{k 4} e_{j} \Delta \ln \text { Pakista }_{t-j}+\sum_{j=0}^{k 5} f_{j} \Delta \ln \text { SouthAfrica }_{t-j}+\sum_{j=0}^{k 6} g_{j} \Delta \ln U S A(S \& P 500)_{t-j} \\
& +n_{1} \ln \text { Pakista }_{t-1}+n_{2} \ln \text { Brazil }_{t-1}+n_{3} \ln \text { Russia }_{t-1}+n_{4} \ln \text { India }_{t-1} \\
& +n_{5} \ln \text { China }_{t-1}+n_{6} \ln \text { SouthAfrica }_{t-1}+n_{7} \ln U S A(S \& \text { P500) }
\end{aligned}
$$

\section{Model 12.}

$$
\begin{aligned}
& \Delta \ln \text { SouthAfrica }_{t}=\alpha_{0}+\sum_{j=1}^{k 1} b_{j} \Delta \ln \text { Brazil }_{t-j}+\sum_{j=0}^{k 2} c_{j} \Delta \ln \text { Russia }_{t-j}+\sum_{j=0}^{k 3} d_{j} \Delta \ln \text { India }_{t-j} \\
& +\sum_{j=0}^{k 4} e_{j} \Delta \ln \text { China }_{t-j}+\sum_{j=0}^{k 5} f_{j} \Delta \ln \text { Pakista }_{t-j}+\sum_{j=0}^{k 6} g_{j} \Delta \ln U S A(S \& P 500)_{t-j} \\
& +n_{1} \ln \text { Pakista }_{t-1}+n_{2} \ln \text { Brazil }_{t-1}+n_{3} \ln \text { Russia }_{t-1}+n_{4} \ln \text { India }_{t-1} \\
& +n_{5} \ln \text { China }_{t-1}+n_{6} \ln \text { SouthAfrica }_{t-1}+n_{7} \ln U S A(S \& \text { P500) }
\end{aligned}
$$

The above specifications of Error Correction Models show several signs of summation, which are termed to signify E.C.M.s. Moreover, to understand the long-term relationship, the term $n_{s}$ is expressed in the E.C.M.s. To identify the null-hypotheses for long-term relationship (No Cointegration) is postured as:

$$
\begin{aligned}
& H_{0}=n_{1}=n_{2}=n_{3}=n_{s}=0 \text {. If } H_{0} \neq 0, \text { so it associates with alternative hypotheses mean } \\
& H_{1}=n_{s} 6=0
\end{aligned}
$$

It is performed through the F-test, where the critical values have elasticity or variation among the variable, expressed as I (0) or I (1). The hypothesis acceptance and rejection are based on upper and lower bound levels of F-statistics. The rejection region of the null hypothesis falls if the upper bound level is less than the calculated Fstatistics. On the contrary, if the lower bound level is higher than the calculated F-statistics, then it is impossible to reject the null-hypotheses. If the results would influence the first aspect, then we say that there is no evidence of cointegration among study variables. If results fall in the second aspect, then we may state cointegration evidence among study variables. There might be uniqueness in results if the calculated f-stat falls in between lower and upper bound levels, though, it ensures that the results are convincing (Pesaran et al., 1996). To estimate the relative quality of the A.R.D.L. model for a given set of data, we have used the Akaike Information Criterion (A.I.C.). Moreover, A.I.C. estimates the mean of selected models, or it gives the trade-off point between the goodness of fit and simplicity of the study model.

\section{Results}

Descriptive analysis. Table 2 summarises the whole data set in the descriptive statistics. The descriptive statistics show some exciting elements in the dataset, which would influence our further chosen statistical models. The highest volatility is observed in the Russian stock market, and this stock market deviates by 0.031 , which is relatively high compared to others. Contrary, the Pakistani stock exchange, particularly the KSE-100 index, is relatively less volatile; it deviates by 0.016 .

Moreover, it shows completely different results compared to other countries' stock markets. The std. deviation of India shows 0.019 and $-0.112,0.14$ as a minimum and maximum values. China and South Africa are relatively high volatile compared to Pakistan, India, and Brazil, showing 0.021 and 0.029 deviations. 
Tab. 2. Descriptive Statistics

\begin{tabular}{ccccc}
\hline Variables & Minimum & Maximum & Mean & Std. Deviation \\
\hline Pakistan & -0.04 & 0.078 & 0.00067 & 0.016 \\
\hline Brazil & -0.117 & 0.127 & 0.00031 & 0.020 \\
\hline Russia & -0.49 & 0.598 & 0.00042 & 0.031 \\
\hline India & -0.112 & 0.14 & 0.00049 & 0.019 \\
\hline China & -0.086 & 0.26 & 0.00016 & 0.021 \\
\hline South Africa & -0.692 & 0.198 & -0.00005 & 0.029 \\
\hline
\end{tabular}

Results of A.R.D.L. (Long-term and Short-term). As we mentioned that the A.R.D.L. approach removes the issue of unit root of data set and stationarity at the level. However, we have input the data series, which includes the log-returns of stocks. Furthermore, we have estimated the E.C.M.s by using appropriate lag length. The estimations of A.R.D.L. models are represented in Table 3, having both long-term and short-term outcomes for all the prescribes models of the study. Table 3 is categorized into three panels. Panel-A includes the longterm relationship among study variables, Panel-B refers to short-term dynamics, and finally, Panel-C depicts lower and upper Bound test.

Moreover, in the long-term dynamics, Panel-A directs to the lagged values of study variables, which gives the forecast about endogenous index in the prescribed model — taking the example of the Brazilian stock market, which is at negative endogenous index with Indian stock market. This endogenous index is handy for speculators (native and international) to predict and derive the quick maximum advantage from the portfolio diversification.

LT represents the long-term, and ST signifies the short-term. The Panel-A includes extensive evidence to forecast the future value of related indices. This forecasting is based on the lagged value and variable results. Moreover, the study chooses the endogenous index for each variable, like for Pakistan; KSE-100 is taken as an endogenous index. The results may help managers of mutual fund companies or fund managers for each member of the BRICS(P) group.

Results from Model-7. In the long-run relationship (Panel-A), it is found that the Pakistani stock market with South Africa earns no benefit of investment diversification because both stock markets move simultaneously. The relationship between both economies is statistically significant, with a positive relationship. Moreover, Panel-A shows irrelevant results of Pakistan's Stock Market with the U.S.A., India, Russia, and China. Therefore, investors of Pakistan may enjoy diversification gains by merging their portfolio investment with these growing economies (U.S.A., India, Russia, China).

Results from Model-8. In the long-run relationship (Panel-A), it is investigated that, Brazilian stock market is negatively correlated with the Indian stock market, and it is statistically significant. Moreover, it is observed that the speculators of Brazil could have investment diversifications benefits in the stock markets of Pakistan and China. The statistical results show that given economies are correlated insignificantly, the USA S\&P500 has the same position as Brazil. On the other hand, Brazilian investors may not enjoy the diversification gains in Russia and South Africa. A positive correlation of the Brazilian stock market is associated with Russian and South African stock markets.

Results from Model-9. In the long-run relationship (Panel-A), It is observed that the Russian investors can secure investment diversification benefits in the stock markets of Pakistan, India, and Russia. An insignificant relationship exists in the given economies. Moreover, a significant link is found in South Africa and US S\&P500 with Brazil, which means that there is no benefit of investment diversification for Russian investors.

Results from Model-10. In the long-run relationship (Panel-A), it is examined that the Indian stock market is statistically insignificant and negatively correlated with Pakistani, South African, US S\&P500, and Brazilian Stock markets, which refers to the portfolio investors of India can derive benefits from investment diversification.

Results from Model-11. In the long-run relationship (Panel-A), it is found that China has an insignificant relationship with US SP500, Pakistan, Russia, and Brazil. The correlation among given economies encourages the investors of china to earn diversification gains by investing portfolios in US S\&P500, Pakistan, Russia, and Brazil.

Results from Model-12. In the long-run relationship (Panel-A), it is investigated that the South African stock market has an insignificant correlation with the stock markets of Russia, Pakistan, Brazil, US S\&P500, and India. Therefore, investors can invest their portfolios in the given stock markets to reap the benefits of investment diversification.

Furthermore, a short-run relationship is observed in Panel-B. It is observed that the cointegration is significant, as the E.C.M.s Models from Eq. (7) to Eq. (12) is found statistically significant. Following is the interpretation of the short-run relationship among the BRIC(P) group. 
Results from Model -7 (E.C.M.). In the short run relationship (Panel-B), it is observed that the investors of the Pakistani stock market earn no short-run benefits over all the stock markets of BRICS. The E.C.M. results are statistically significant.

Results from Model-8 (E.C.M.). The short-run relationship (Panel-B) found that the Brazilian stock market has a short-term impact on US S\&P500 and Russian stock markets. However, Brazil consists of no short-run effect on the rest of the other stock markets in the Group.

Results from Model-9 (E.C.M.). In the short run relationship (Panel-B), it is investigated that the Russian stock market is affected in the short run with the Indian stock market and the Brazilian stock market. However, the case is unaffected rest of the other members of the Group.

Results from Model-10 (E.C.M.). In the short run relationship, it is explored that Russian and Chinese funds have centred short-run effects on the Indian market. Moreover, the short-run effect is far from other members of the Group.

Results from Model-11 (E.C.M.). The short-run relationship shows that the Chinese Stock market has a short-term effect on the stock markets of South Africa and India. No short-run effect is found from other economies in China.

Results from Model-12 (E.C.M.). In the short run relationship (Panel-B), it is observed that the stock market of South Africa is affected if short-run volatility exists in the Chinese stock market. However, the rest of the other markets in the Group have no short-run effect on the stock market of South Africa.

Following the work of (Pesaran et al., 1996), A.R.D.L. Bound test is used to investigate the cointegration among the study variables. Moreover, F-statistics in the bound test is used as an indicator for the existence of cointegration or no cointegration. The rule to reject the null hypothesis that there is no cointegration among the study variables is possible when the U-Bound value becomes less than calculated F-stats.

Results from A.R.D.L. Bound Test. For cointegration, Panel-C shows that the U-Bound values are lesser than the calculated F-Stats, which rejects the null hypothesis. It means that cointegration with long-run relationship exists among the study variables.

Tab. 3. Long-tern \& short-term estimates

\begin{tabular}{|c|c|c|c|c|c|c|}
\hline \multicolumn{7}{|c|}{ Dependent Variables Coefficient / (p-value) } \\
\hline Regressors & Pakistan & Brazil & Russia & India & China & South Africa \\
\hline Lag Length & $\begin{array}{l}(4,0,4,0,1, \\
1,2)\end{array}$ & $\begin{array}{l}(3,0,3,2, \\
2,4,2)\end{array}$ & $\begin{array}{c}(4,2,2,1, \\
4,0,4)\end{array}$ & $\begin{array}{l}(2,0,0,0,3, \\
0,0)\end{array}$ & $\begin{array}{l}(4,2,0,0,0, \\
0,1)\end{array}$ & $\begin{array}{l}(4,4,0,0,0 \\
0,0)\end{array}$ \\
\hline & 0.0004 & 0.0029 & 0.0002 & 0.0003 & 0.0004 & -0.0001 \\
\hline $\mathrm{C}$ & $(0.0124)$ & $(0.134)$ & $(0.321)$ & $(0.051)$ & $(0.443)$ & $(0.730)$ \\
\hline Pakistan & - & $\begin{array}{r}-0.026 \\
(0.4040) \\
\end{array}$ & $\begin{array}{r}0.036 \\
(0.281) \\
\end{array}$ & $\begin{array}{r}-0.034 \\
(0.157) \\
\end{array}$ & $\begin{array}{r}0.0243 \\
(0.188) \\
\end{array}$ & $\begin{array}{r}0.006 \\
(0.566) \\
\end{array}$ \\
\hline BRAZIL & $\begin{array}{r}0.034 \\
(0.212) \\
\end{array}$ & - & $\begin{array}{r}0.006 \\
(0.611) \\
\end{array}$ & $\begin{array}{r}-0.0011 \\
(0.818) \\
\end{array}$ & $\begin{array}{r}-0.021 \\
(0.233) \\
\end{array}$ & $\begin{array}{r}-0.0033 \\
(0.633) \\
\end{array}$ \\
\hline RUSSIA & $\begin{array}{r}0.032 \\
(0.124)\end{array}$ & $\begin{array}{r}0.063 \\
(0.000)\end{array}$ & - & $\begin{array}{r}0.054 \\
(0.000)\end{array}$ & $\begin{array}{r}-0.0042 \\
(0.423)\end{array}$ & $\begin{array}{r}0.006 \\
(0.341)\end{array}$ \\
\hline INDIA & $\begin{array}{r}0.032 \\
(0.216) \\
\end{array}$ & $\begin{array}{r}-0.053 \\
(0.0223) \\
\end{array}$ & $\begin{array}{r}0.027 \\
(0.308) \\
\end{array}$ & - & $\begin{array}{r}0.0487 \\
(0.006) \\
\end{array}$ & $\begin{array}{r}-0.020 \\
(0.227) \\
\end{array}$ \\
\hline CHINA & $\begin{array}{r}0.012 \\
(0.339) \\
\end{array}$ & $\begin{array}{r}0.021 \\
(0.123) \\
\end{array}$ & $\begin{array}{r}0.061 \\
(0.062) \\
\end{array}$ & $\begin{array}{r}0.052 \\
(0.005) \\
\end{array}$ & - & $\begin{array}{r}0.037 \\
(0.003) \\
\end{array}$ \\
\hline SOUTH AFRICA & $\begin{array}{r}0.030 \\
(0.042) \\
\end{array}$ & $\begin{array}{r}0.0663 \\
(0.0039) \\
\end{array}$ & $\begin{array}{r}0.065 \\
(0.0054) \\
\end{array}$ & $\begin{array}{r}-0.0087 \\
(0.253) \\
\end{array}$ & $\begin{array}{r}0.0525 \\
(0.000)\end{array}$ & - \\
\hline & 0.0062 & 0.0184 & 0.055 & -0.028 & -0.0166 & 0.0042 \\
\hline S\&P500 & $(0.744)$ & $(0.423)$ & $(0.072)$ & $(0.210)$ & $(0.341)$ & $(0.787)$ \\
\hline \multicolumn{7}{|c|}{ Panel-B: Short-Term Estimates } \\
\hline D(PAKISTAN) & - & $\begin{array}{r}0.034 \\
(0.111) \\
\end{array}$ & $\begin{array}{r}0.038 \\
(0.352) \\
\end{array}$ & $\begin{array}{r}-0.022 \\
(0.206) \\
\end{array}$ & $\begin{array}{r}0.0221 \\
(0.214) \\
\end{array}$ & $\begin{array}{r}0.014 \\
(0.664) \\
\end{array}$ \\
\hline D(BRAZIL) & $\begin{array}{r}0.017 \\
(0.130)\end{array}$ & - & $\begin{array}{r}0.109 \\
(0.0006)\end{array}$ & $\begin{array}{r}-0.001 \\
(0.821)\end{array}$ & $\begin{array}{r}0.023 \\
(0.166)\end{array}$ & $\begin{array}{r}0.029 \\
(0.310)\end{array}$ \\
\hline
\end{tabular}




\begin{tabular}{|c|c|c|c|c|c|c|}
\hline D(RUSSIA) & $\begin{array}{r}0.005 \\
(0.421) \\
\end{array}$ & $\begin{array}{r}0.0453 \\
(0.000) \\
\end{array}$ & - & $\begin{array}{r}0.031 \\
(0.012) \\
\end{array}$ & $\begin{array}{r}-0.0049 \\
(0.613) \\
\end{array}$ & $\begin{array}{r}0.0055 \\
(0.377) \\
\end{array}$ \\
\hline D(INDIA) & $\begin{array}{r}-0.0139 \\
(0.125) \\
\end{array}$ & $\begin{array}{r}-0.0017 \\
(0.535) \\
\end{array}$ & $\begin{array}{r}0.081 \\
(0.008) \\
\end{array}$ & - & $\begin{array}{r}0.0433 \\
(0.006) \\
\end{array}$ & $\begin{array}{r}-0.019 \\
(0.317) \\
\end{array}$ \\
\hline D(CHINA) & $\begin{array}{r}0.018 \\
(0.253) \\
\end{array}$ & $\begin{array}{r}0.0301 \\
(0.1504) \\
\end{array}$ & $\begin{array}{r}-0.0051 \\
(0.743) \\
\end{array}$ & $\begin{array}{c}0.032 \\
(0.006) \\
\end{array}$ & - & $\begin{array}{r}0.058 \\
-0.002 \\
\end{array}$ \\
\hline $\begin{array}{l}\text { D(SOUTHAFR } \\
\text { ICA) }\end{array}$ & $\begin{array}{l}0.0031 \\
(0.781)\end{array}$ & $\begin{array}{l}0.0135 \\
(0.219)\end{array}$ & $\begin{array}{c}0.023 \\
(0.297)\end{array}$ & $\begin{array}{l}-0.006 \\
(0.319)\end{array}$ & $\begin{array}{l}0.0222 \\
(0.003)\end{array}$ & - \\
\hline & 0.003 & 0.0311 & 0.062 & -0.02 & -0.0121 & 0.002 \\
\hline $\mathrm{D}(\mathrm{S} \& \mathrm{P} 500)$ & $(0.911)$ & $(0.061)$ & $(0.060)$ & $(0.199)$ & $(0.441)$ & $(0.995)$ \\
\hline & -0.675 & -1.022 & -1.266 & -0.921 & -0.897 & -1.171 \\
\hline CointEq(-1) & $(0.000)$ & $(0.000)$ & $(0.000)$ & $(0.000)$ & $(0.000)$ & $(0.000)$ \\
\hline \multicolumn{7}{|c|}{ Panel-C: A.R.D.L. Bound Test } \\
\hline F-Stat & 82.142 & 171.4 & 172.22 & 212.133 & 98.661 & 124.431 \\
\hline $\begin{array}{l}\text { Upper Bound } \\
\text { Critical Value }\end{array}$ & 5.23 & 5.23 & 5.23 & 5.23 & 5.23 & 5.23 \\
\hline
\end{tabular}

Moreover, a summarized view of A.R.D.L. tests is illustrated in Table 4 for the ease of reading, in which members among BRICS(P) group could have more chances to earn the portfolio diversification benefits in the long run and short run. Both Panels A and B explain that if the result of the coefficient is statistically negative, it does not matter whether it is significant or insignificant it does refer that investors of that member group may enjoy diversification benefits. Contrary, if the coefficients are statically positive and significant, then it means there is no space for investors to reap the portfolio diversification benefits.

\begin{tabular}{|c|c|c|c|c|c|c|c|c|c|c|c|c|}
\hline \multirow{2}{*}{ Investors from } & \multicolumn{2}{|c|}{ Pakistan } & \multicolumn{2}{|c|}{ Brazil } & \multicolumn{2}{|c|}{ Russia } & \multicolumn{2}{|c|}{ India } & \multicolumn{2}{|c|}{ China } & \multicolumn{2}{|c|}{ South Africa } \\
\hline & $\mathrm{LT}$ & ST & $\mathrm{LT}$ & ST & LT & ST & LT & ST & LT & ST & $\mathrm{LT}$ & ST \\
\hline Pakistan & - & - & Yes & Yes & Yes & Yes & Yes & Yes & Yes & Yes & Yes & Yes \\
\hline Brazil & Yes & Yes & - & - & No & No & Yes & Yes & Yes & Yes & Yes & Yes \\
\hline Russia & Yes & Yes & No & No & - & - & No & No & Yes & Yes & Yes & Yes \\
\hline India & Yes & Yes & No & Yes & Yes & No & - & - & No & No & Yes & Yes \\
\hline China & Yes & Yes & Yes & Yes & No & Yes & No & No & - & - & Yes & No \\
\hline South Africa & Yes & Yes & No & Yes & No & Yes & Yes & Yes & No & No & - & - \\
\hline S\&P 500 & Yes & Yes & Yes & No & No & No & Yes & Yes & Yes & Yes & Yes & Yes \\
\hline
\end{tabular}

\section{Discussion}

This study intends to investigate the benefits of international portfolio diversification, which can be reaped by the investors/speculators of BRICS(P) group. This study aims to examine the short and long-run investment benefits associated with the BRICS(P) Group. To achieve the oriented object of this study, we collected secondary data from Yahoo Finance, which is an authentic source to collect refined financial data of several stock indices. This study includes seven indices only. Linking the BRICS-(P) Group, we cover the sampled countries of Brazil, Russia, India, China, South Africa, and Pakistan, which is suitable to represent the concept of emerging economies at a global level (Rao \& Padhi, 2020; Ahmed et al., 2018a). E.C.M. and A.R.D.L. model, respectively, test this study induced to collect Monthly data from November-2012 to October-2018 and short-run and long-run relationships. The given statistical techniques are very significant to investigate cointegration compared to traditional approaches. The long-run relationship among BRICS(P) shows that all investors belong from that Group may earn substantial benefits by diversifying their respective portfolio investments.

Moreover, this study result supports the past studies on benefits on portfolio investment diversification among evolving economies like (Opoku-Mensah et al., 2019; Zonouzi et al., 2014). One of the studies shows 
that the economic volatility between the developed and developing world brings certain good factors for portfolio investors in diversifying their investment structures (Ahmed et al., 2018b; Sukumaran et al., 2015). This study also included the US S\&P500, which is one of the leading global stock markets in the world. The reason to add US S\&P500 is to investigate the dependency of the BRICS(P) group on this leading stock market. The study results regarding the US S\&P500 refer that no longer run and short-run dependence occurs on the returns index of the US S\&P500 except the Russian stock market (Bhoi, 2019). It is found that there is an uneven structure that leads the B.I.C.S.P. (Brazil, India, China, South African, and Pakistan) to cointegration without inducing the US S\&P500. This study result supports the finding of Grubel (1968). Lastly, one of the significant implications of this study is to understand portfolio diversification benefits between two economies, which are highly cointegrated in the Group. The following members are Pakistan and India. There is a possibility of both long and short-run investment diversification benefits for investors of given economies. It is crucial for economists, policymakers, and speculators to understand the untapped mutual benefits between these two growing economies. It is observed that policymakers of both countries should make ease for investors to diversify their funds, and that would also lead to more prosperous and optimal economic conditions for both countries.

\section{Conclusions}

This study is motivated by the portfolio mechanism. The statement, "Portfolio risk is better than stand-alone risk," hors d'oeuvre for researchers to contribute their findings in fulfilment of portfolio concepts, and this study efforted to do the same. This study supports the context of portfolio diversification that it is better to diversify funds in the global emerging markets to reap maximum investment returns with minimal risk. Thou, this study had taken the BRICS(P) group to investigate whether the benefits of portfolio investment diversification exist or not. The outcomes of this study exposed that this emerging market has a high potential for investors so they can enjoy portfolio returns. It is the notion that investors who are willing and able to invest in the emerging market must consider associated risk factors like economic risk, political risk, social risk, etc. There should be a reconciliation between extreme volatility of emerging market and investment return. However, investment diversification has some significant advantages in that native investors hedged the investment by diversifying funds to other member countries in the Group, like the recession in the economy, devaluation of home currency, etc. This study recommends significant policy implications for investors as well as for policymakers. Firstly, it provides some implicit measures for investors to maximize their investment return and reduce the risk ratio by diversifying their investments. Thou, investors may reduce the risk bubble, and there would be ease in placing an optimal portfolio structure in BRICS(P) group. Secondly, it is directing to policymakers (Government) to reap benefits by diversifying their potential investment portfolios in this emerging market. However, that would help raise government funds to enhance the economic power and run better financial operations.

Moreover, the study result made an inference about the adequate investment diversification between two growing economies, Pakistan and India. Despite the economic risk and unmatched political situations between these two economies, it is investigated that investors may earn mutual investment returns. However, nonsmoothness in political dialogues and negotiations reduced the optimization of co-investors, foreign investment is ignored where high political risk exists. However, the developing country investor tends to invest in a strong market where they could earn a suitable return. Still, owing to some uncertain domestic conditions, they could have faced loss. Though, it is felt that there is a need to make specific financial policies by which both economies (Pakistan \& India) may diversify funds without hesitation. It is possible when both countries show their willingness to have a positive and constructive dialogue.

\section{References}

Ahmed, R. R., Vveinhardt, J., \& Štreimikienè, D. (2018). Multivariate Granger Causality between oil and gold prices, and KSE100 index: Evidence from Johansen cointegration and G.A.R.C.H. approaches. Acta Montanistica Slovaca, 23(2), 216-231. https://actamont.tuke.sk/pdf/2018/n2/10streimikiene.pdf

Ahmed, R. R., Vveinhardt, J., Štreimikienè, D., Ghauri, S. P., \& Ashraf, M. (2018). Stock Returns, Volatility and Mean Reversion in Emerging and Developed Financial Markets. Technological and Economic Development of Economy, 24(3), 1149-1177. http://dx.doi.org/10.3846/20294913.2017.1323317

Bahlous, M., \& Yusof, R. M. (2014). International diversification among Islamic investments: is there any benefit. Managerial Finance, 40(6), 613-633. https://doi.org/10.1108/mf-08-2013-0225

Batareddy, M., Gopalaswamy, A. K., \& Huang, C.-H. (2012). The stability of long-run relationships: A study on Asian emerging and developed stock markets (Japan and U.S.). International Journal of Emerging Markets, 7(1), 31-48. https://doi.org/10.1108/17468801211197888 
Bhoi, B. K. (2019). Can BRICS countries escape the middle-income trap? Macroeconomics and Finance in Emerging Market Economies, 12(3), 293-296. https://doi.org/10.1080/17520843.2019.1615970

Boubaker, S., \& Jouini, J. (2014). Linkages between emerging and developed equity markets: Empirical evidence in the P.M.G. framework. The North American Journal of Economics and Finance, 29, 322-335. https://doi.org/10.1016/j.najef.2014.06.004

Cosset, J.-C., \& Suret, J.-M. (1995). Political risk and the benefits of international portfolio diversification. Journal of International Business Studies, 26(2), 301-318. https://doi.org/10.1057/palgrave.jibs.8490175

Dhanaraj, S., Gopalaswamy, A. K., \& Babu M, S. (2013). Dynamic interdependence between the U.S. and Asian markets: an empirical study. Journal of Financial Economic Policy, 5(2), 220-237. https://doi.org/10.1108/17576381311329670

Dunis, C., Sermpinis, G., \& Ferenia Karampelia, M. (2013). Stock market linkages among new EMU members and the euro area: Implications for financial integration and portfolio diversification. Studies in Economics and Finance, 30(4), 370-388. https://doi.org/10.1108/sef-04-2012-0048

Fatima, Z., \& Shamim, M. (2020). The Dynamic Nexus between G.D.P., Consumption and Exports of BRICS Countries: An A.R.D.L. Cointegration Analysis. International Journal of Trade and Global Markets, 13(3). https://doi.org/10.1504/ijtgm.2020.10021570

Ghauri, S. P., Ahmed, R. R., Arby, M. F., \& Martinkute-Kauliene, R. (2020). Assessment of Effects of Relative Price Variability on Inflation. Transformations in Business \& Economics, 19, No. 1 (49), 306-322. Available online http://www.transformations.knf.vu.lt/49/article/asse

Grubel, H. G. (1968). Internationally diversified portfolios: welfare gains and capital flows. The American Economic Review, 58(5), 1299-1314. https://doi.org/10.3386/w4340

Guidi, F., \& Ugur, M. (2014). An analysis of South-Eastern European stock markets: Evidence on cointegration and portfolio diversification benefits. Journal of International Financial Markets, Institutions, and Money, 30, 119-136. https://doi.org/10.1016/j.intfin.2014.01.007

Hoque, H. A. A. B. (2007). Co-movement of Bangladesh stock market with other markets: Cointegration and error correction approach. Managerial Finance, 33(10), 810-820. https://doi.org/10.1108/03074350710779250

Huang, B., \& Fang, X. (2019). Market Sentiment, Valuation Heterogeneity, and Corporate Investment: Evidence from China's A-Share Stock Market. Emerging Markets Finance and Trade. https://doi.org/10.1080/1540496x.2019.1672531

Huang, N., Huang, Z., \& Wang, W. (2019). The Dynamic Extreme Co-Movement between Chinese Stock Market and Global Stock Markets. Emerging Markets Finance and Trade, 55(14), 3241-3257. https://doi.org/10.1080/1540496x.2018.1529559

Johnson, R., \& Soenen, L. (2009). European economic integration and stock market comovement with Germany. Multinational Business Review,17(3),205-228. https://doi.org/10.1108/1525383x200900024

Laurenceson, J., \& Chai, J. C. (2003). Financial reform and economic development in China: Edward Elgar Publishing. https://doi.org/10.4337/9781843767190

Lekovic, M. (2018). Investment diversification as a strategy for reducing investment risk. Journal of Ekonomski horizonti, 20(2), 173-187. https://doi.org/10.5937/ekonhor18021731.

Levy, H., \& Sarnat, M. (1970). Diversification, portfolio analysis, and the uneasy case for conglomerate mergers. The Journal of Finance, 25(4), 795-802. https://doi.org/10.1111/j.1540-6261.1970.tb00553.x

Li, K., Sarkar, A., \& Wang, Z. (2003). Diversification benefits of emerging markets subject to portfolio constraints. Journal of Empirical Finance, 10(1-2), 57-80. https://doi.org/10.1016/s0927-5398(02)00027$\underline{0}$

Lintner, J. (1975). The valuation of risk assets and the selection of risky investments in stock portfolios and capital budgets Stochastic Optimization Models in Finance (pp. 131-155): Elsevier. https://doi.org/10.2307/1926735

Longin, F., \& Solnik, B. (1995). Is the correlation in international equity returns constant: 1960-1990? Journal of international money and finance, 14(1), 3-26. https://doi.org/10.1016/0261-5606(94)00001-h

Markowitz, H. (1952). Portfolio selection. The Journal of Finance, 7(1), 77-91. https://doi.org/10.1111/j.1540$\underline{6261.1952 . t b 01525 . x}$

Mei, G., \& McNown, R. (2019). Dynamic causality between the U.S. stock market, the Chinese stock market and the global gold market: implications for individual investors' diversification strategies. Applied Economics, 51(43), 4742-4756. https://doi.org/10.1080/00036846.2019.1601156

Mobarek, A., \& Li, M. (2014). Regional volatility: common or country-specific? Exploration of the international stock market. Studies in Economics and Finance, 31(4), 406-425. https://doi.org/10.1108/sef-04-2013$\underline{0051}$

Narayan, P. K., \& Narayan, S. (2006). Savings behaviour in Fiji: an empirical assessment using the A.R.D.L. approach to cointegration. International journal of social economics, 33(7), 468-480. https://doi.org/10.1108/03068290610673243 
Okwu, A. T., Oseni, I. O., \& Obiakor, R. T. (2020). Does Foreign Direct Investment Enhance Economic Growth? Evidence from 30 Leading Global Economies. Global Journal of Emerging Market Economies. https://doi.org/10.1177/0974910120919042

Opoku-Mensah, E., Yin, Y., Sandra, A. A., \& Tuffour, P. (2019). Mergers and Acquisitions Antecedents in BRICS. Global Journal of Emerging Market Economies, 11(3), 202-214. https://doi.org/10.1177/0974910119887241

Ozturk, H., \& Karabulut, T. A. (2020). Impact of financial ratios on technology and telecommunication stock returns: evidence from an emerging market. Investment Management and Financial Innovations, 17(2), 76-87. https://doi.org/10.21511/imfi.17(2).2020.07

Parveen, S., Satti, Z. W., Subhan, Q. A., \& Jamil, S. (2020). Exploring market overreaction, investors' sentiments and investment decisions in emerging stock market. Borsa Istanbul Review. https://doi.org/10.1016/j.bir.2020.02.002

Patev, P., Kanaryan, N., \& Lyroudi, K. (2006). Stock market crises and portfolio diversification in Central and Eastern Europe. Managerial Finance, 32(5), 415-432. https://doi.org/10.1108/03074350610657436

Pesaran, M. H., Shin, Y., \& Smith, R. J. (1996). Testing for the existence of a Long-run Relationship. https://doi.org/10.1016/0304-4076(94)01644-f

Rao, B. M., \& Padhi, P. (2020). Macroeconomic costs of currency crises in BRICS: an empirical analysis. Macroeconomics and Finance in Emerging Market Economies. https://doi.org/10.1080/17520843.2020.1749103

Rua, A., \& Nunes, L. C. (2009). International comovement of stock market returns A wavelet analysis. Journal of Empirical Finance, 16(4), 632-639. https://doi.org/10.1016/j.jempfin.2009.02.002

Salisu, A. A., \& Oloko, T. F. (2015). Modelling spillovers between the stock market and F.X. market: evidence for Nigeria. Journal of African Business, 16(1-2), 84-108. https://doi.org/10.1080/15228916.2015.1061285

Sharpe, W. F. (1964). Capital asset prices: A theory of market equilibrium under conditions of risk. The Journal of Finance, 19(3), 425-442. https://doi.org/10.1111/j.1540-6261.1964.tb02865.x

Sivarethinamohan, R., \& Sujatha, S. (2019). Econometric Modelling: Testing of Randomness,Volatility, Casualty and Cointegration of Emerging Stock Market Indices of India and MIST Countries. International Journal of Innovative Technology and Exploring Engineering, 9(2), 1402-1417. https://doi.org/10.35940/ijitee.a4946.129219

Sukumaran, A., Gupta, R., \& Jithendranathan, T. (2015). Looking at new markets for international diversification: frontier markets. International Journal of Managerial Finance, 11(1), 97-116. https://doi.org/10.1108/ijmf-05-2013-0057

Tsagkanos, A., Siriopoulos, C., \& Vartholomatou, K. (2019). Foreign direct investment and stock market development. Journal of Economic Studies, 46(1), 55-70. https://doi.org/10.1108/jes-06-2017-0154

Valadkhani, A., Chancharat, S., \& Harvie, C. (2008). A factor analysis of international portfolio diversification. Studies in Economics and Finance, 25(3), 165-174. https://doi.org/10.1108/10867370810894693

Wang, L. (2019). Stock Market Valuation, Foreign Investment, and Cross-Country Arbitrage. Global Finance Journal, 40, 74-84. https://doi.org/10.1016/j.gfj.2018.01.004

Zonouzi, S. J. M., Mansourfar, G., \& Azar, F. B. (2014). Benefits of international portfolio diversification: Implication of the Middle Eastern oil-producing countries. International Journal of Islamic and Middle Eastern Finance and Management, 7(4), 457-472. https://doi.org/10.1108/imefm-02-2014-0017 